\title{
IMPACT OF IRRIGATION AND DRAINAGE ON MAIZE (Zea mays) YIELD, SOME WATER RELATIONS AND NITROGEN FERTILIZER LOSSES IN THE NORTH MIDDLE NILE DELTA. Moursi, E.A.; A.A.S. Gendy and M.M. Kassab Soils, Water and Environment Research Institute Agric. Res. Center
}

\begin{abstract}
A field trail was conducted at Sakha Agricultural Research Station, Kafr EISheikh Governorate, during the two successive growing seasons 2008 and 2009 to study the effect of number of irrigations on maize yield, its components and some water relationships. Moreover, to investigate the effect of irrigation treatments on nitrogen fertilizer losses such as $\mathrm{NH}_{4}^{+}$and $\mathrm{NO}_{3}{ }_{3}$ in drainage water. The experimental design was randamized complete block with three replicates. The irrigation treatments were randomly assigned as main treatments which are, 1- lirrigation as local farmers irrigating, their fields in the studied area (traditional, or control treatment A), 2Withholding one irrigation through the growing season (treatment, B), 3-Withholding two irrigations through the growing season (treatment, $C$ ) and 4- Withholding three irrigations through the growing season (treatment, D).

The obtained results can be summarized as follows :-

- The highest values of water applied and water consumptive use were recorded under control treatment (irrigation without any stress during the growing season, treatment, A).On the contrary, the lowest values were recorded under treatment, $D$ (skipping three irrigations during the growing season).

- The mean values of both water utilization and water use efficiencies were increased under stressed plants comparing with control treatment,A. The highest mean values were recorded under treatment, $D$ but the lowest mean values were recorded under control treatment, $A$ (traditional irrigation).

- The mean values for yield and its components of maize were decreased under water stressed treatments B,C and D compared with the non-stressed one (traditional irrigation). The mean values for all studied parameters can be decreased in order $A, B$, C > D.

- Data also showed that the differences between A and B treatments was extremely slight for all studied parameters. So, the researchers might be recommended to skipping one irrigation during the growing season instead of the traditional irrigation, without any loss of yield.

- The losses for both $\mathrm{NH}_{4}^{+}$and $\mathrm{NO}_{3}^{-}$was increased under control treatment comparing with other stress irrigation treatments $B, C$, and $D$ which exposed to different stress treatments during the two growing seasons. Also, data showed that the losses of $\mathrm{NO}_{3}^{-}$ion was higher than $\mathrm{NH}_{4}^{+}$losses. Increasing losses of $\mathrm{NH}_{4}^{+}$and $\mathrm{NO}_{3}^{-}$due to application of fertilizers as one dose, so, application of fertilizers should be splitted into several doses.

- According to rate of water table drawdown in the two growing seasons, the rate was decreased with increasing time following irrigation event. The highest value of water table drawdown was found after one day from irrigation. On the other hand, the lowest value was found before the next irrigation. The highest values of discharge rate were found in the first day after irrigation, while the lowest values were found before the next irrigation.
\end{abstract}


Moursi, E.A. et al.

\section{INTRODUCTION}

Maize grain is an important agricultural production in Egypt. The majority of farmers are still using maize grains for baking. Also, maize grains give a good type of edible oil. Therefore, this crop plays an important role in solving the shortage of edible oil which may be reached more than $90 \%$.Maize is also utilized for animal feeding. The average national productivity of maize is about $30 \mathrm{ardab} / \mathrm{Fed}$.( $\operatorname{ardab}=150 \mathrm{~kg})$.So, maize productivity should be increased to face the need for people and animals. Increasing productivity of maize grain can be happened either by cultivation high productivity verities and the proper technical packages. Regarding cultivation activities among these irrigation management is an important tool. So, irrigation process should be controlled from the beginning of the growing season till the end of it.

Besides giving careness to irrigation we should do our best to care with drainage system in the studied area. This could be reduced the level of water table and decreasing the fertilizers losses particularly the nitrogenous 1 which polluted the drainage water and that hindrances re-using of it again and that needs a great treatment to become available for using again .Besides interests with irrigation and drainage that help to grow healthy plants which give high yield.

Agricultural production in Egypt, almost entirely depends on irrigation with water from the Nile River, as rainfall amount is negligible. Approximately all the national cultivation area of 8 million feddan (3.36 million ha.)is irrigated. The Egyptian water budget is limited to the country's share of the Nile which is fixed according to international agreements.

The main proplem which faces Egyptian agriculture is the limitation of irrigation water because of scarcity of water resources and fixed of Egyptian water budget which is 55.5 milliard cubic metre.Agricultural sector requires more than $85 \%$ from this amount. So, under conditions of limited water supply, particularly those of good qualities, the studies of the actual water requirements of crops become essential. The cultivable maize area is about 2 million feddan ( $1 \mathrm{fed}=0.42 \mathrm{ha}$ ). Therefore, the accurate knowledge of the amount of water required to produce the highest economical grain yield of maize is essential. Also, in planning for irrigation of maize it becomes necessary to know about the quantity of water consumed in growing this crop and the efficiency of the applied water.

\section{The main objectives for this study were to:}

* studying some water relations for maize in the studied area.

* Identification of the best water regime which is suitable for maize.

* Decreasing the pressure on the drainage network in the studied area.

* Decreasing the fertilizer losses as well as decreasing pollution of drainage water. 


\section{MATERIALS AND METHODS}

To achieve the main target of role of irrigation and drainage on maize and its water relations, a field experiment was carried out at Sakha Agricultural Research Station, Kafr El-Sheikh Governorate in the North Middle Nile Delta region during the two growing seasons 2008/2009. The soil texture of this experimental site is clayey.

\section{Experimental layout:}

Maize as a summer crop was planted on 1st July and 18th June in the first and second growing seasons, respectively. Harvesting was preformed on $20^{\text {th }}$ and $30^{\text {th }}$ October in the first and second growing seasons, respectively. Maize cultivar was single white hybrid 123.

* Soil chemical and physical properties of the studied site:

Soil chemical properties were determined according to black et al.(1965). Physical properties such as field capacity (F.C.) was determined at the site. Permanent wilting point (P.W.P) was determined according to James(1988) and soil bulk density was determined according to Vomacil (1957). The particle size distribution was determined according to the international method of (Klute, 1962). The soil is clayey in texture and the soil profile is uniform without distinct change in texture. Available water was determined according to James(1988).

Table (1): The mean values of some soil chemical properties of the experimental site before cultivation in the two growing seasons.

\begin{tabular}{|c|c|c|c|c|c|c|c|c|c|c|}
\hline \multirow{2}{*}{\begin{tabular}{|c|} 
Soil depth \\
(cm)
\end{tabular}} & \multirow{2}{*}{$\begin{array}{l}E C \\
\mathrm{dsm}^{-1}\end{array}$} & \multirow{2}{*}{ pH } & \multicolumn{4}{|c|}{ Soluble cations $\mathrm{MeqL}^{-1}$} & \multicolumn{4}{|c|}{ Soluble anions $\mathrm{MeqL}^{-1}$} \\
\hline & & & $\mathrm{Ca}^{2+}$ & $\mathbf{M g}^{2+}$ & $\mathrm{Na}^{+}$ & $\mathrm{K}^{+}$ & $\mathrm{Co}_{3}^{2-}$ & $\mathrm{HCO}_{3}^{-}$ & $\mathrm{Cl}^{-}$ & $\mathrm{So}_{4}^{2-}$ \\
\hline $0-15$ & 1.5 & 8.15 & 0.30 & 0.10 & 0.76 & 0.02 & - & 0.55 & 0.21 & 0.42 \\
\hline $15-30$ & 1.57 & 8.00 & 0.31 & 0.10 & 0.79 & 0.02 & - & 0.57 & 0.22 & 0.43 \\
\hline $30-45$ & 1.65 & 8.00 & 0.34 & 0.10 & 0.89 & 0.02 & - & 0.65 & 0.23 & 0.47 \\
\hline $45-60$ & 2.78 & 7.90 & 0.84 & 0.27 & 1.25 & 0.03 & - & 0.45 & 0.23 & 1.71 \\
\hline
\end{tabular}

Table (2): The mean values of some soil Physical properties and some water constants of the experimental site before cultivation in the two growing seasons.

\begin{tabular}{|c|c|c|c|c|c|c|c|c|}
\hline \multirow{2}{*}{$\begin{array}{c}\text { Soil } \\
\text { Depth } \\
\text { cm. }\end{array}$} & \multicolumn{2}{|c|}{$\begin{array}{c}\text { Particle size } \\
\text { distribution }\end{array}$} & \multirow{2}{*}{$\begin{array}{c}\text { Texture } \\
\text { class }\end{array}$} & F.C \% & $\begin{array}{c}\text { P.W.P } \\
\%\end{array}$ & $\begin{array}{c}\text { Available } \\
\text { Water\% }\end{array}$ & $\begin{array}{c}\text { Bulk } \\
\text { density } \\
\mathbf{K g} / \mathbf{m}^{3}\end{array}$ \\
\hline $0-15$ & 16.0 & 18.0 & 66.0 & Clay & 47.0 & 25.3 & 21.7 & 1.19 \\
\hline $15-30$ & 19.0 & 13.0 & 68.0 & Clay & 39.0 & 21.8 & 17.2 & 1.16 \\
\hline $30-45$ & 16.5 & 16.0 & 67.5 & Clay & 38.0 & 21.9 & 16.1 & 1.30 \\
\hline $45-60$ & 17.5 & 15.5 & 67.0 & Clay & 38.5 & 20.8 & 17.7 & 1.20 \\
\hline
\end{tabular}

Statistical analysis: -

Data collected were subjected to the statisticaly analysis according to Snedecor and Cochran (1967).

The experimental design was randomized completely block with three replicates. the irrigation treatments were randomly assigned where they were:

1. Treatment $A$, Control traditional irrigation like local farmers irrigating their fields in the studied area without water stress 
Moursi, E.A. et al.

2. Treatment, Bwithholding one irrigation through the growing season,

3. Treatment, $C$ withholding two irrigations through the growing season and

4. Treatment, $D$ withholding three irrigations through the growing season.

The area of each irrigation plot was $72 \mathrm{~m}^{2}\left(3 \mathrm{~m}\right.$ width ${ }^{\star} 24 \mathrm{~m}$ length).all cultivated practices were executed as recommended for the crop in the studied area except the investigated parameters.

\section{Data collection:}

\section{Applied irrigation water.}

The irrigation flow rate per plot was calculated according to Isrealsen and Hansen equation (1962)

Where:

$$
q=0.0226 D^{2} h^{0.5}
$$

$\mathrm{q}=$ =irrigation flow rate $\mathrm{cm}^{3} / \mathrm{sec}$,

$\mathrm{h}=$ average effective head, and

$\mathrm{D}=$ inside diameter of the pipe,cm. The amount of water applied for each plot was calculated by using formula

Where :

$$
a=q^{*} T
$$

$\mathrm{a}=$ water volume $/$ plot $\mathrm{m}^{3}$

$\mathrm{q}=$ irrigation flow rate $\mathrm{cm}^{3}$ and

$T=$ total recorded time for each plot, minute

2. Water utilization efficiency (W.Ut.E)

(W.Ut.E) was calculated according to Michael (1978)

Where:

$(\mathrm{W} . \mathrm{Ut} . \mathrm{E})=\mathrm{Y} / \mathrm{Wa}$

W.Ut.E $=$ water utilization efficiency $\left(\mathrm{kg} / \mathrm{m}^{3}\right)$

$\mathrm{Y}=$ Marketable yield, $\mathrm{kg} / \mathrm{fed}$. and

$\mathrm{Wa}=$ Water applied, $\mathrm{m}^{3} / \mathrm{fed}$.

\section{Water use efficiency (W.U.E.)}

The water use efficiency as a measure to clarify variations in yield due to irrigation water consumed, which was calculated according to Michael (1978) as Follows

Where

$$
\text { W.U.E }=Y / C U
$$

W.U.E = water use efficiency, $\mathrm{kg} / \mathrm{m}^{3}$

$\mathrm{Y}=$ Marketable yield $\mathrm{kg} / \mathrm{fed}$. and

$\mathrm{CU}=$ water consumed, $\mathrm{m}^{3} /$ Fed.

\section{Water consumptive use (C.U.)}

Water consumptive use by growing plants was calculated based on soil moisture depletion (SMD) according to Hansen et al.(1979)

$$
\begin{aligned}
& \mathrm{Cu}=\mathrm{SMD}=\sum \sum_{\mathrm{i}=1} \frac{\Theta 2-\Theta 1}{100} * \mathrm{Dbi} \\
& \text { Where } \\
& \mathrm{Cu}=\text { water consumptive use }(\mathrm{cm}) \text { in the effective root zone }(60 \mathrm{~cm}) . \\
& \Theta_{2}=\text { Gravimetric soil moisture percentage after irrigation } \\
& \Theta_{1}=\text { Gravimetric soil moisture percentage before irrigation }
\end{aligned}
$$

Where 
$\mathrm{Dbi}=$ Soil bulk density $\left(\mathrm{kg} / \mathrm{m}^{3}\right)$ for depth

$\mathrm{Di}=$ soil layer depth $(15 \mathrm{~cm}$.)

$\mathrm{I}=$ number of soil layers (1-4)

5-Losses ammonium and nitrate in drainage and soil water:

Total soluble nitrogen (ammonium nitrogen+ nitrate nitrogen ).Total soluble nitrogen determined using devardas alloy powder (a).Ammonium nitrogen determined without devards alloy powder (b).

Nitrate nitrogen $=a-b$

Yield and yield components

- Grain yield (ardab/fed.

- Weight of $100 \mathrm{grains}(\mathrm{g})$

- Ear diameter (cm.).

- Number of lines/ear.

- Number of grains/line.

- Plant height at harvesting (cm.)

- Ear height (cm.).

- Stem diameter (cm.).

\section{RESULTS AND DISCUSSION}

Water applied for maize $\mathrm{m}^{3} /$ fed.

Tabulated data in Table (3) clearly illustrated that the values of irrigation water applied for maize are greatly affected by irrigation regime. The values of water applied were the highest under control treatment (Trt., A, without holding any irrigation through the growing season) comparing with other stressed treatments. Water applied for treatment (A) are 4037.66 and $3943.8 \mathrm{~m}^{3} / \mathrm{fed}$. in the first and second growing seasons, respectively. The values of irrigation water applied in the two growing seasons can be descended in this order $A>B>C>D$. On the contrary, the lowest values of 2461.73 and $2577.88 \mathrm{~m}^{3} / \mathrm{fed}$., were recorded under the condition of (Trt.D, with skipping three waterings) in the two growing seasons, respectively. Increasing the values of irrigation water applied under the condition of (Trt, A) is due to increasing number of irrigations. These results are in a great harmony with those obtained by El arquan and Abdel Kariem (1982), Ibrahim et al.(2005) and Awad et al. (2009)

Table (3): Effect of irrigation water regime on maize water applied in the two growing seasons

\begin{tabular}{|c|c|c|}
\hline \multirow{2}{*}{ Irrigation treatment } & \multicolumn{2}{|c|}{ Water applied $\left(\mathbf{m}^{\mathbf{3}} / \mathbf{f e d}\right.$.) } \\
\cline { 2 - 3 } & $\mathbf{1}^{\text {st }}$ season & $\mathbf{2}^{\text {nd }} \mathbf{s e a s o n}$ \\
\hline $\mathrm{A}$ & 4037.66 & 3943.80 \\
\hline $\mathrm{B}$ & 3672.91 & 3712.97 \\
\hline $\mathrm{C}$ & 3102.70 & 3161.97 \\
\hline $\mathrm{D}$ & 2461.78 & 2577.88 \\
\hline
\end{tabular}

Where : A: traditional irrigation (without skipping irrigation )

B: Skipping one irrigations during the growing seasons

C: Skipping two irrigations during the growing seasons

D: Skipping three irrigation during the growing seasons 
Water consumptive use for maize, $\mathrm{m}^{3} / \mathrm{fed}$ :

Presented data in Table (4) showed that the values of consumptive use for maize are affected by irrigation treatments where the highest values were recoreded under control treatment $(A)$, which practiced by local farmers . The values are 2753.2 and $2706.6 \mathrm{~m}^{3} / \mathrm{fed}$. in the first and second growing seasons, respectively. on the contrary, the lowest values were recorded under treatment $\mathrm{D}$ (Skipping three irrigations during the growing season) and the corresponding values are 1807.7 and $1557.0 \mathrm{~m}^{3} / \mathrm{fed}$., respectively. The values of consumptive use for maize in the studied area can be descended in order $\mathrm{A}>\mathrm{B}>\mathrm{C}>\mathrm{D}$ in the two growing seasons. Increasing the values of consumptive use for maize under control treatment might be attributed due to the enough available water .Therefore, the values of consumptive use increased under such condition comparing with other irrigation treatments. Generally, seasonal water consumptive use decreased as soil available water amount decreased. The results are in a great agreement with those obtained by EL arquan and Abd el-Kariem (1982), Faizy et al. (1986) who indicated that the values of maize consumptive use were increased by decreasing irrigation interval from 28 days to 14 days. Also, results are in the same line with those obtained by Ashoub et al. (1996), Horder et al.(1982), Ibrahim et al. (2005) and Awad et al. (2009).

Table (4): Effect of irrigation water regime on maize consumptive use in the two growing seasons.

\begin{tabular}{|c|c|c|c|c|}
\hline \multirow{2}{*}{$\begin{array}{l}\text { Irrigation } \\
\text { treatment }\end{array}$} & \multicolumn{4}{|c|}{ consumptive use } \\
\cline { 2 - 5 } & \multicolumn{2}{|c|}{$\mathbf{1}^{\text {st }}$ season } & \multicolumn{2}{c|}{$\mathbf{2}^{\text {nd }}$ season } \\
\cline { 2 - 5 } & $\mathrm{m}^{3} / \mathrm{fed}$ & $\mathrm{cm}$ & $\mathrm{m}^{3} / \mathrm{fed}$. & $\mathrm{cm}$ \\
\hline $\mathrm{A}$ & 2753.20 & 65.54 & 2706.58 & 64.44 \\
\hline $\mathrm{B}$ & 2534.35 & 60.33 & 2568.08 & 61.13 \\
\hline $\mathrm{C}$ & 2192.22 & 52.20 & 2237.48 & 53.27 \\
\hline $\mathrm{D}$ & 1807.67 & 43.04 & 1557.03 & 44.92 \\
\hline
\end{tabular}

Water utilization and use efficiencies $\left(\mathrm{kg} / \mathrm{m}^{3}\right.$.)

Data in Table (5) showed that the values of both water utilization and use efficiencies were increased under increasing water stress conditions. The highest values were recorded under (Trt. D) in the two growing seasons. The values of both two crop water efficiencies can be descended in the order $\mathrm{D}>\mathrm{C}>\mathrm{B}>\mathrm{A}$. These results are in a great harmony with those obtained by Faizy et al.(1986), Ibrahim et al.(2005) and Awad et al. (2009).

Table (5): Effect of irrigation water regime on maize water efficiencies in the two growing seasons.

\begin{tabular}{|c|c|c|c|c|}
\hline \multirow{2}{*}{$\begin{array}{l}\text { Irrigation } \\
\text { treatment }\end{array}$} & \multicolumn{2}{|c|}{$\begin{array}{l}\text { Water utilization efficiency } \\
\left(\mathrm{kg} / \mathrm{m}^{3}\right)\end{array}$} & \multicolumn{2}{|c|}{$\begin{array}{c}\text { Water use efficiency } \\
\left(\mathrm{kg} / \mathrm{m}^{3}\right)\end{array}$} \\
\hline & $1^{\text {st }}$ season & $2^{\text {nd }}$ season & $1^{\text {st }}$ season & $2^{\text {nd }}$ season \\
\hline $\mathrm{A}$ & 1.09 & 1.12 & 1.60 & 1.63 \\
\hline$B$ & 1.15 & 1.18 & 1.67 & 1.70 \\
\hline $\mathrm{C}$ & 1.23 & 1.26 & 1.74 & 1.78 \\
\hline$D$ & 1.35 & 1.38 & 1.83 & 2.28 \\
\hline
\end{tabular}


Yield and yield components :

Presented data in Table (6) clearly showed that the mean values of both yield and yield components are affected by the studied irrigation treatments in the two growing seasons. The mean values of both yield and its components of maize were decreased under water stressed conditions of $B, C$, and $D$ compared with the non-stressed treatment which gave the highest mean values for the studied parameters in the two growing seasons. The mean values for all for the studied parameters can be descended in order $A>B>C>D$. Where the lowest mean values were recorded under treatment $D$ which exposed to strict water stress, skipping or missing three irrigations during the season. The results showed that the reduction in yield between (Trt.A and B) for all yield and yield components in the two growing seasons were very slight.

Table (6): Effect of irrigation regime on yield and yield components of maize in the two growing seasons

\begin{tabular}{|c|c|c|c|c|c|c|c|c|}
\hline \multirow{2}{*}{ Yield } & \multirow{2}{*}{ Seasons } & \multicolumn{4}{|c|}{ Irrigation treatment } & \multirow{2}{*}{$F_{\text {test. }}$} & \multirow{2}{*}{ LSD $_{5 \%}$} & \multirow{2}{*}{$\operatorname{LSD}_{1 \%}$} \\
\hline & & A & B & C & D & & & \\
\hline \multirow{2}{*}{$\begin{array}{l}\text { Grain yield } \\
\text { (ardb/Fed) }\end{array}$} & $1^{s t}$ & 29.443 & 28.243 & 25.387 & 22.093 & $* *$ & 1.55 & 2.84 \\
\hline & 2 nd & 29.393 & 29.097 & 26.520 & 23.660 & $* *$ & 2.06 & 3.78 \\
\hline \multirow{2}{*}{$\begin{array}{l}100 \text { grain } \\
\text { weight }(\mathrm{g})\end{array}$} & $1^{\text {st }}$ & 39.34 & 38.29 & 36.11 & 35.04 & ** & 2.15 & 3.95 \\
\hline & 2nd & 38.58 & 37.65 & 36.01 & 34.68 & $* *$ & 1.91 & 3.51 \\
\hline \multirow{2}{*}{$\begin{array}{c}\text { Ear } \\
\text { diameter }(\mathrm{cm})\end{array}$} & $1^{\text {st }}$ & 17.27 & 16.87 & 16.47 & 16.07 & $* *$ & 1.18 & 2.05 \\
\hline & $2_{\text {nd }}$ & 16.86 & 16.47 & 16.07 & 16.07 & $* *$ & 0.83 & 1.53 \\
\hline \multirow{2}{*}{$\begin{array}{l}\text { Ear length } \\
(\mathrm{cm})\end{array}$} & $1^{\text {st }}$ & 20.08 & 20.47 & 20.23 & 20.03 & ** & 0.67 & 1.24 \\
\hline & $2 n d$ & 20.40 & 20.20 & 20.23 & 20.13 & $* *$ & 0.67 & 1.23 \\
\hline \multirow{2}{*}{$\begin{array}{l}\text { Number of } \\
\text { rows in ear }\end{array}$} & $1^{\text {st }}$ & 14.67 & 14.27 & 14.00 & 13.77 & ** & 0.73 & 1.34 \\
\hline & 2 nd & 14.53 & 14.20 & 14.17 & 14.07 & ** & 0.656 & 1.20 \\
\hline \multirow{2}{*}{$\begin{array}{l}\text { Number of } \\
\text { grains in row }\end{array}$} & $1^{\text {st }}$ & 48.5 & 47.8 & 46.77 & 46.37 & ** & 1.05 & 1.93 \\
\hline & 2 nd & 49.13 & 48.76 & 46.66 & 46.00 & ** & 1.32 & 2.79 \\
\hline \multirow{2}{*}{$\begin{array}{l}\text { Plant height } \\
(\mathrm{cm})\end{array}$} & $1^{\text {st }}$ & 296.67 & 295.0 & 226.33 & 165.0 & ** & 26.61 & 48.84 \\
\hline & 2nd & 300.0 & 298.0 & 242.0 & 172.2 & ** & 25.28 & 46.41 \\
\hline \multirow{2}{*}{$\begin{array}{l}\text { Ear height } \\
(\mathrm{cm})\end{array}$} & $1^{\text {st }}$ & 138.0 & 137.0 & 129.30 & 93.0 & ** & 21.89 & 40.19 \\
\hline & 2 nd & 138.0 & 137.3 & 128.0 & 91.0 & ** & 13.62 & 25.00 \\
\hline \multirow{2}{*}{$\begin{array}{c}\text { Stem } \\
\text { diameter } \mathrm{cm}\end{array}$} & $1^{\text {st }}$ & 9.3 & 9.0 & 8.6 & 7.3 & ** & 3.182 & 5.841 \\
\hline & 2 nd & 9.0 & 8.3 & 7.6 & 6.6 & ** & 3.181 & 5.841 \\
\hline
\end{tabular}

Increasing yield and yield components under control treatment in the two growing seasons might be due to increasing amount of available nutrients and hence increasing amount of nutrients uptake so, forming strong plants with good vegetative growth were reflected on yield and yield components. Therefore, increasing yield and its components was obtained under treatment $(A)$ comparing with other irrigation treatments which exposed to water stress. These results are in a great harmony with those obtained by Elarquan and Abdel Kariem(1982) who indicated that both yield and yield components for $20 \%$ soil moisture deficit treatment exceeded that of $50 \%$ and $80 \%$ of soil moisture deficit.From data obtained the authors can be recommended under the conditions of the studied area which suffer from limitation of irrigation water resources maize can be exposed to water stress 
Moursi, E.A. et al.

by missing or skipping one irrigation during the growing period without any drastic effect on yield and yield components because the difference between treatments $A$ and $B$ is slight. Under limitation of irrigation water resources maize can be skipped one irrigation through its growing period without any bad effect on yield and yield components. This skipping irrigation saves a large amount of irrigation water on the national level, such amount of water saving can be used in irrigating other crops in the same crop rotation or others. These results are in a great harmony with those obtained by Harder et al.(1982) Who showed that grain yield of maize was reduced by $33 \%$ due to the severity and duration of soil moisture stress. Also, these results are in a great agreement with those obtained by Ibrahim et al.(2005).and Awad, et al. (2009))

$\mathrm{NH}_{4}^{+}$and $\mathrm{NO}_{3}^{-}$losses in groundwater:

Presented data in Table (7) clearly showed that the losses of both $\mathrm{NO}_{3}$ and $\mathrm{NH}_{4}^{+}$were affected by days after irrigation where the meanvalues were decreased by elongation days after irrigation. The highest mean values were recorded in the first day after irrigation comparing with the other days which gave the low values for $\mathrm{NO}_{3}^{-}$and $\mathrm{NH}_{4}^{+}$. Also data in the same table illustrated that the mean values of $\mathrm{NO}_{3}^{-}$were higher than values of $\mathrm{NH}_{4}^{+}$in the two growing seasons. This might be due to that on the first day after irrigation the amount of drainage water is high. So, the leaching rate also is high and consequently the content of $\mathrm{NO}_{3}$ and $\mathrm{NH}_{4}^{+}$were higher in groundwater in the first day after irrigation comparing with other days.

Table (7): Effect of irrigation regime on losses of $\mathrm{NH}_{4}^{+}$and $\mathrm{NO}^{-3}$ in groundwater in the two growing seasons

\begin{tabular}{|c|c|c|c|}
\hline Days after irrigation & Observation well & $\mathrm{NH}_{4}^{+}$ & $\mathrm{NO}_{3}^{-}$ \\
\hline \multirow{4}{*}{ - } & $\mathrm{P} 1$ & 70.0 & 70.0 \\
\hline & $\mathrm{P} 2$ & 49.0 & 49.0 \\
\hline & P3 & 21.0 & 108.0 \\
\hline & P4 & 10.5 & 136.5 \\
\hline \multirow{4}{*}{2} & P1 & 21.0 & 91.0 \\
\hline & P2 & 35.0 & 526.0 \\
\hline & P3 & 49.0 & 959.0 \\
\hline & P4 & 17.5 & 290.5 \\
\hline \multirow{4}{*}{3} & P1 & 10.5 & 115.0 \\
\hline & P2 & 28.0 & 140.0 \\
\hline & P3 & 7.0 & 112.0 \\
\hline & P4 & 14.0 & 143.0 \\
\hline \multirow{4}{*}{4} & P1 & 7.0 & 197.0 \\
\hline & $\mathrm{P} 2$ & 17.0 & 73.5 \\
\hline & P3 & 7.0 & 133.0 \\
\hline & P4 & 10.5 & 108.5 \\
\hline \multirow{4}{*}{5} & $\mathrm{P1}$ & 10.5 & 94.5 \\
\hline & P2 & 14.0 & 616.0 \\
\hline & P3 & 7.0 & 504.0 \\
\hline & P4 & 17.0 & 270.0 \\
\hline
\end{tabular}

Increasing the values of $\mathrm{NO}_{3}^{-}$ion in groundwater comparing with $\mathrm{NH}_{4}^{+}$ because of increasing leaching rate of $\mathrm{NO}_{3}^{-}$comparing with $\mathrm{NH}_{4}^{+}$which adsorbed on clay particles in comparison with $\mathrm{NO}_{3}^{-}$which has a high solubility rate. So, its content in drainage water is high comparing with $\mathrm{NH}^{+}{ }_{4}$ 
ion. The amount of $\mathrm{NO}_{3}^{-}$and $\mathrm{NH}_{4}^{+}$losses at the end of growing season is $7.3 \mathrm{~kg} / \mathrm{Fed}$. But the losses through the growing season is $29.0 \mathrm{~kg} / \mathrm{Fed}$. Because the fertilization is applied as one dose. Data also in the same table indicated that the amount of $\mathrm{NO}_{3}^{-}$and $\mathrm{NH}_{4}^{+}$loses through observation well (1)which installed in control treatment (irrigated during fixed period through the whole growing season without any stress) is very high comparing with other observation wells which put in other irrigation treatments which exposed to stress during the growing season. Increasing losses of $\mathrm{NO}_{3}^{-}$and $\mathrm{NH}_{4}^{+}$ might be due to application of fertilizers as one dose comparing with application it in different doses (3 doses instead of one dose) which leads to decreasing rate of losses. These results are in a great harmony with those obtained S.A.Ramadan et al.(2004 and 2009)

\section{Rate of water table drawdown:}

As shown in Fig. (1 and 2) and table 8 the calculated rate of drawdawn in both studied seasons was decreased with increasing interval after irrigation. The highest values of drawdown were found a after one day following irrigation event. While the lowest values were found before the next irrigation. This may be due to the improvement of tile drainage which in return gave the top soil chance to dry and permitted for shrinkage and formation of water passage ways and allowed a rather easier movement of water into drain pipes. These results are in a great harmony with those obtained by S.A. Ramadan et al. (2009)

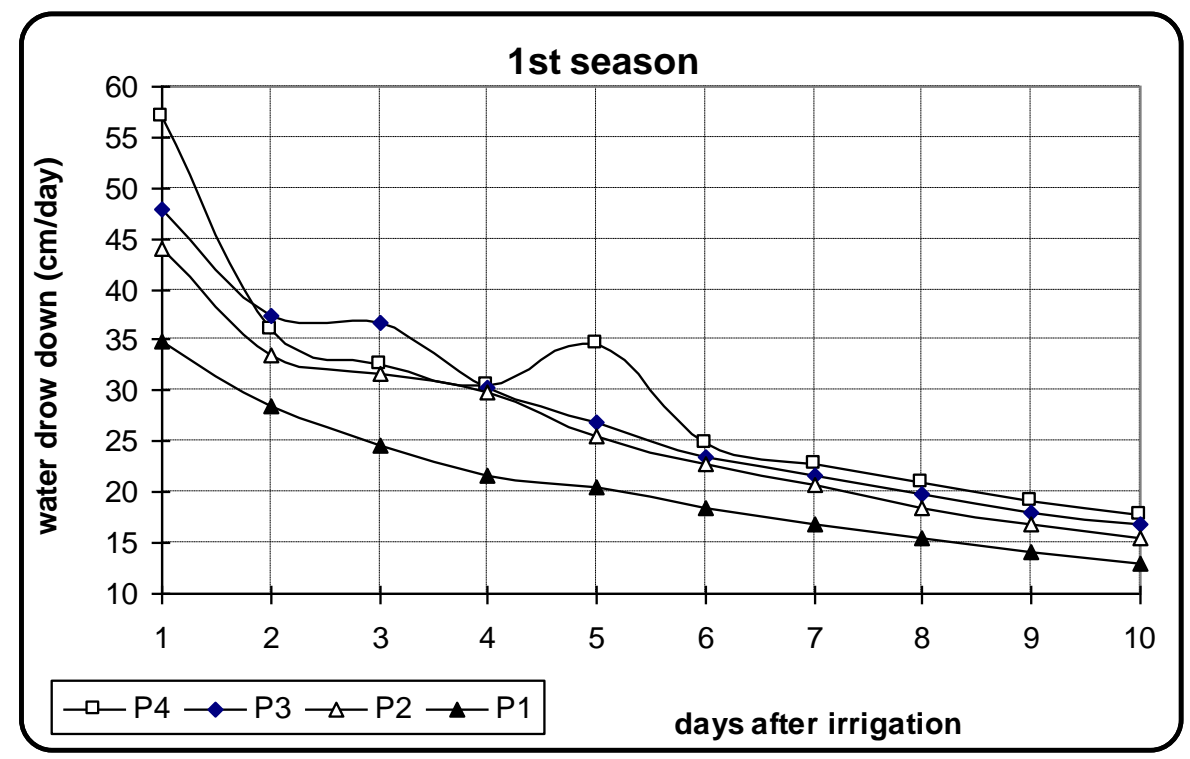

Fig.(1): Average watertable drawdown rate under maize (Zea mays) crop in 2008 season 


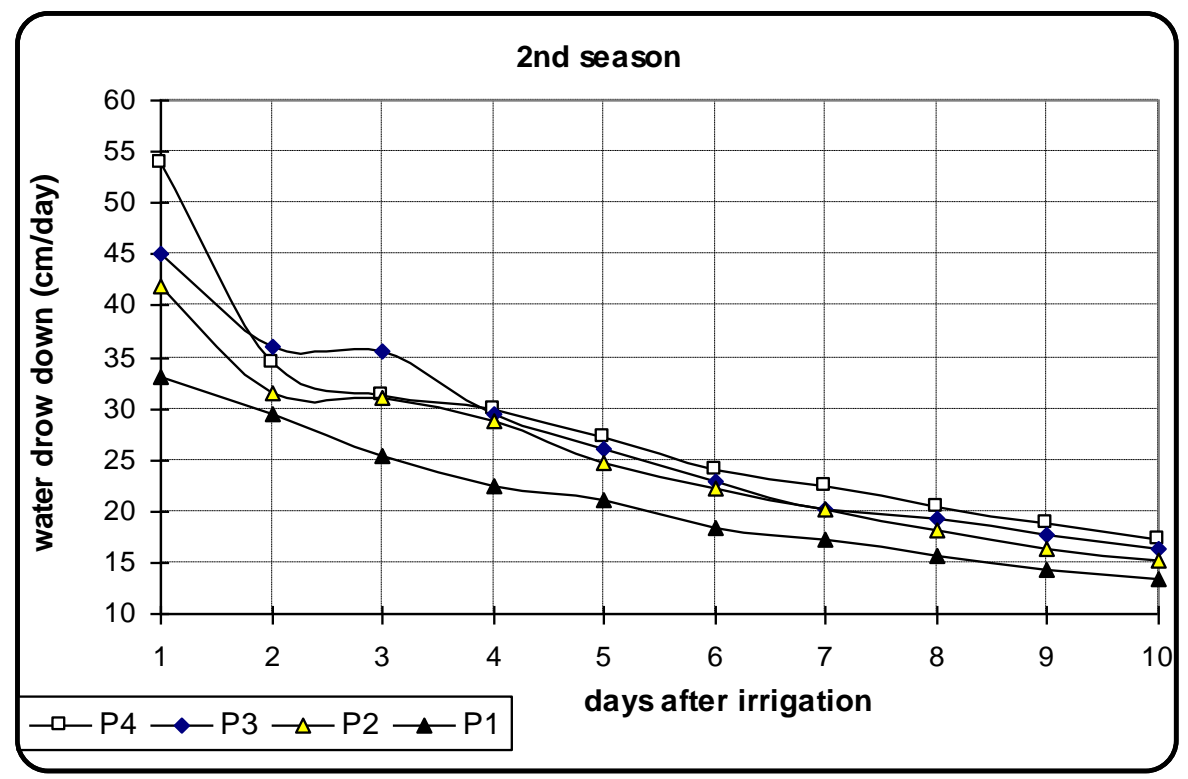

Fig. (2): Average watertable drawdown rate under maize (Zea mays) crop in 2009 season

Table (8): Effect of irrigation regime on water table drawdown rate (cm) in the two growing seasons.

\begin{tabular}{|c|c|c|c|c|c|c|c|c|}
\hline \multirow{2}{*}{$\begin{array}{c}\text { Days after } \\
\text { irrigation }\end{array}$} & \multicolumn{7}{|c|}{ Water table draw down rate, cm day } \\
\cline { 2 - 9 } & \multicolumn{7}{|c|}{$\mathbf{1}^{\text {st }}$ season } & \multicolumn{4}{|c|}{$\mathbf{2}^{\text {nd }}$ season } \\
\cline { 2 - 9 } & $\mathbf{P 1}$ & $\mathbf{P 2}$ & $\mathbf{P 3}$ & $\mathbf{P 4}$ & $\mathbf{P 1}$ & $\mathbf{P 2}$ & $\mathbf{P 3}$ & $\mathbf{P 4}$ \\
\hline 1 & 35.0 & 44.0 & 48.0 & 57.0 & 33.0 & 42.00 & 45.00 & 54.00 \\
\hline 2 & 28.5 & 33.5 & 37.5 & 36.0 & 29.50 & 31.50 & 36.00 & 34.50 \\
\hline 3 & 24.67 & 31.67 & 36.67 & 32.67 & 25.33 & 31.0 & 35.67 & 31.33 \\
\hline 4 & 21.75 & 29.75 & 30.25 & 30.50 & 22.50 & 28.75 & 29.50 & 30.00 \\
\hline 5 & 20.6 & 25.60 & 26.8 & 34.75 & 21.00 & 24.80 & 26.00 & 27.20 \\
\hline 6 & 18.5 & 22.83 & 23.5 & 24.83 & 18.33 & 22.33 & 22.83 & 24.00 \\
\hline 7 & 16.86 & 20.71 & 21.71 & 22.86 & 17.29 & 20.29 & 20.29 & 22.43 \\
\hline 8 & 15.50 & 18.5 & 19.75 & 20.88 & 15.75 & 18.25 & 19.38 & 20.50 \\
\hline 9 & 14.11 & 16.76 & 18.0 & 19.11 & 14.22 & 16.44 & 17.67 & 18.89 \\
\hline 10 & 13.00 & 15.5 & 16.90 & 17.80 & 13.5 & 15.20 & 16.40 & 17.20 \\
\hline
\end{tabular}

\section{Drain discharge rate :}

The highest values of drainage discharge rate found in the first day after irrigation, while the lowest values are found before the next irrigation. In general, values of drainage discharge rate for all conditions under the first growing season were higher comparing with second season. The mean values of discharge rate in the first season were $5.88 \mathrm{~mm} /$ day while in the second season were $4.58 \mathrm{~mm} /$ day, respectively. While, the discharge rate was low in the treatments which exposed to stress and this plays an important role for relief the press on the drainage system S.A.Ramadan et al. (2009) 


\section{REFERENCES}

Ashoub, M.A.; A.S.Hassanen; I.M.A.; Abd El-Aziz; M.M. Shahin and M.N. Gohar (1996). Influence of irrigation, nitrogen, zinc and manganese fertilization on yield components of Maize annals Agric., Sci..Ain Shams., Univ. Cairo, 41(2):697-711.

Awad, M.M. ; E,A, Moursi and F, Sh, Sedeek (2009). Effect of missing irrigation, mineral and biofertilizers on sunflower in North Nile Delta region. J, Agric, Sci., Mansoura Univ., 34 (10): 10263-10279.

Black, C.A.; D.D. Evans; L.E. Ensmigger; J.L.White and F.E. Clark (1965).Methods of soil analysis. Amer. Soc. Agron. Inc., Madison, Wisconsin U.S.A.

Faizy, S.E.D.A.; M.Ibrahim; S. Gaheen and M. El. Yamani(1986). Effect of interval of irrigation, level of nitrogen and potassium fertilization on yield and nitrogen uptake by maize .J. Agric. Res. Tanta., Univ., 12(4):1986.

Hansen, V.W.; O.W. Israelsen and Q.E Stringharm (1979). Irrigation. Principles and practices, 4th ed., John Willey and sons, New York.

Harder, H.J.; R.E. Carison and RH.Shaw (1982).Yield and yield components and nutrient content of Maize grains influenced by post -Silking moisture stress. Agron. J. 74(2):275-278

Ibrahim, M.A.A.; N.G. Ainr and S.N.Shalan (2005).Farmer's income at Kfr ElSheikh Governorate as affected by water utilization and use efficiencies (case study).9th Int. Conf. on water technology. sharm El-Sheikh. Egypt, March 17-20, 2005.

Isrealsen, D.W.and V.E.Hansen (1962). Flow of water into and through soils. Irrigation principles and practices.3rd Edition, John Wiley and sons, Inc., New York, N.Y., U.S.A.

James,L.G.(1988). Principles of farm irrigation system design. John. Willey \& sons(ed). New York, pp.543.

KLute, A.(1962). Methods of Soil Analysis part1,"physical and mineralogical methods" with Madison, Wisconsin, U.S.A.

M.Y.S.El arquan and M.A.Abdel-Kariem (1982).Water requirements of corn crop in the Gemmaiza area J. Agric. Sci., Mansoura univ., 7:139151,1982 .

Michael, A.M.(1978). Irrigation theory and practice vikas publishing house PVT, LTd.USA.

Ramadan, S.A.; S.A; A.S. Antar; A.A. El-Leithi and I.E.Nasr El-Din (2009).Impact of different nitrogen forms and $\mathrm{K}$ added on N K loses into drainage water under cotton cultivation in clay soil of North Delta. J. Agric.; Res. Kafr El-Sheikh Univ., 35(2)2009.

Snedecor, W.G. and W.G. Cochran (1967). Statistical Methods.6th ed.Lowa State Univ. USA.

Vomocil, J.A.(1957). Measurements of soil bulk density and penetrability. A review of methods Adv.Agric.9, New York, Landon-Edited by Norman a.g.,pp.159-176. 


\section{Moursi, E.A. et al.}

تأثثير الـري والصرف على محصدول الذرة الثـامية وبعض العلاقات المائية وفقد

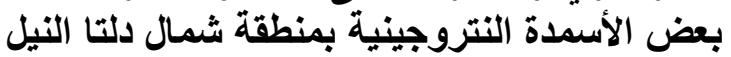

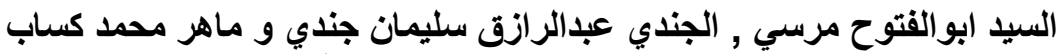
معهد بحوث الاراضي والتياه والبيئه- مركز البحوث الزئي الزراعية

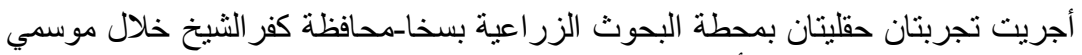

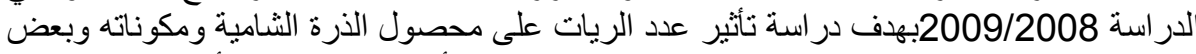

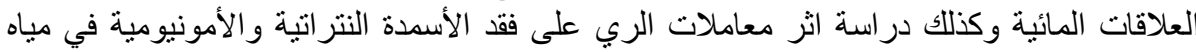

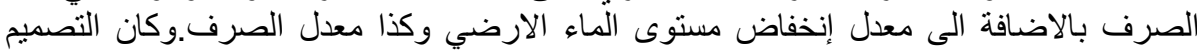

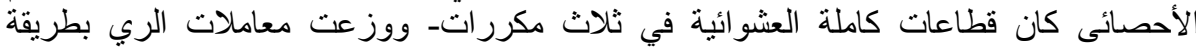

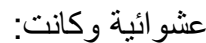

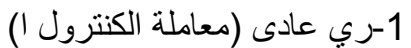

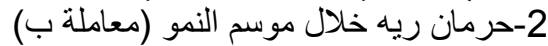

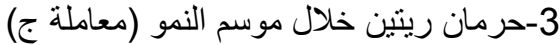

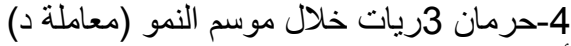

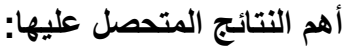

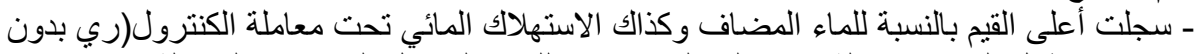
حرمان طول الموسم معاملة ا ) و وعلى العكس من ذللك سجلت اقل القيم تحت المعاملة القيلة د حرمان 3

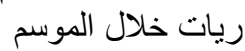

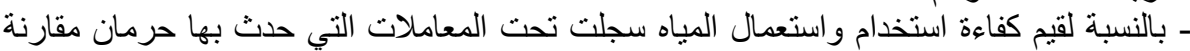

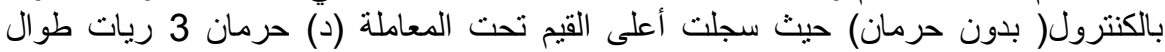

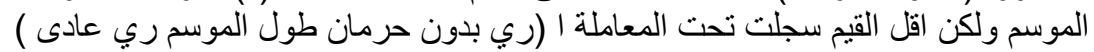

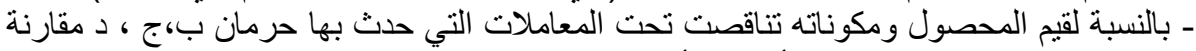

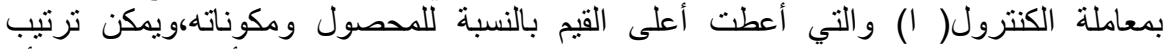

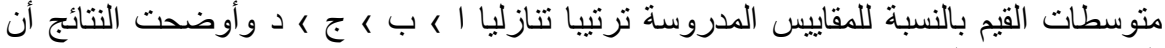
الفروق بين ا،ب ليست معنوية.

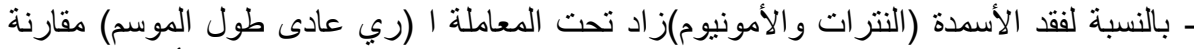

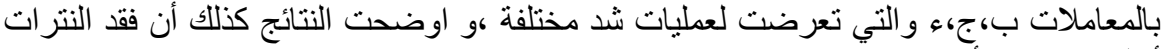

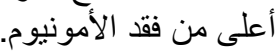
- بالنسبة لمستوى الماء الأرضي معدل الانخفاض تناقص مع زيادة الوقت بعد الري) حيث سجلت

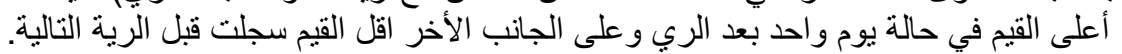
ـ أعلى القيم بالتسبة لمعدل التصرف كان في اليوم الأول بعد الري بينما اقل القيم سجلت قبل التبل الرية التية

كلية الزراعة - جامعة المنصورة

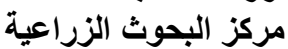

قام بتحكيم البحث

أ. أد / السيد محمود فوزي البدي الحديدي أ.د / محمد عبد الفتاح محمد إبراهيم 
J. Soil Sci. and Agric. Eng., Mansoura Univ., Vol. 2 (1): 59 - 70, 2011 